Research Article

\title{
Effects of Organic Amendments by Composts and Manure on Pepper (Capsicum annuum L.) under Greenhouse
}

\author{
Nejib Turki $^{\dot{\mathrm{A}}^{*}}$ and Karima Kouki Khalfallah ${ }^{\dot{\mathrm{A}}}$ \\ ${ }^{\dot{A}}$ Institut National Agronomique de Tunisie(INAT), 43 Avenue Charles Nicolle 1082 Tunis-Tunisia
}

Accepted 21April 2014, Available online 01 June 2014, Vol.4, No.3 (June 2014)

\begin{abstract}
Four types of organic amendments were evaluated on two varieties, Chargui and starter, of pepper (Capsicum annuum L. ) under greenhouse. Six treatments were given : cattle manure (DM) to 55t/ha, German commercial compost (CG) 1 t/ha, mixture of $27.5 \mathrm{t} / \mathrm{ha} D M+0.5 \mathrm{t} / \mathrm{ha} C G$ (CGDM), French commercial compost (CF) $2 \mathrm{t} / \mathrm{ha}$, Tunisian commercial compost (CT)10 t/ha and control (TO). Organic amendments allow to improve pepper growing, fruit set, yield in number and weight and earliness. The CGDM,DM and CG led to the best yields in weight and number of fruit Chargui variety, with a maximum improvement of $38 \%$ in the fruit number and $40 \%$ in yield under CT compared to the control. CT, $D M$ and CGDM generated the best yields for the starter variety, with a maximum improvement in the fruit number of $34 \%$ and $51 \%$ in yield of CGDM compared to control. The earliness of pepper was enhanced by organic amendments with a maximum of $64 \%$ of DM compared to control for the variety Chargui and $61 \%$ of CT versus control for var. starter. The behavior of pepper crop under organic amendments on plant height, flowering and fruit quality remains dependent on the varietal response. Amendment by different types of organic matter did not cause effects on stem diameter, number of bifurcation, leaf area and plant dry matter of pepper.
\end{abstract}

Keywords: Compost, organic amendment, pepper, crop parameters, yield, earliness.

\section{Introduction}

Agriculture since the 60s has undergone a revolution that is based on improved high yielding varieties, chemical fertilizers, chemical pesticides and the massive use of nonrenewable energy in order to maximize returns to increase the sufficiency level for continuous increasing population (Beji, 2010). This agricultural intensification puts pressure on ecosystem which leads to decreased soil fertility (Laurence, 1998; Ibrahima et al, 2010; Delate, 2002).

The use of these chemicals (fertilizers and pesticides) is more pronounced in intensive vegetable crops (Odet, 1989). Thereby intensive conventional vegetable crops under greenhouses are often characterized by the use of high doses of inputs such as fertilizers and pesticides with climatic conditions (Temperature and high humidity) and intense mineralization processes of organic matter (OM) in the soil, which can lead in the case of insufficient organic inputs to significant decreases in soil OM (Thuries et al, 2000; Bressoud and Arrufat, 2009).

Fertilization based exclusively on the use of inorganic fertilizers can ensure sustainable soil fertility. The maintenance or improvement of soil fertility requires the maintenance of soil organic matter in the soil which is done by a steady supply of good humus amendments used properly. Organic matter is the basis of soil fertility (Aboudrare, 2009). The addition of exogenous OM

*Corresponding author: NejibTurki increases the cation exchange capacity (CEC) and will help maintain the level of nutrients and stimulate several aspects of soil fertility (Calbrix, 2005).

Organic fertilizers come from various raw animal or vegetable origin, which can be composted (Mustin, 1987). These fertilizers are not soluble in water but most of the items they contain are rapidly mineralizable and available to plants. Compost improves the physical and chemical characteristics of the soil (Mustin, 1987; Fuchs, 2003; Maynard, 2000) brings nitrogen, phosphorus and potassium, but also sulfur, calcium, magnesium and trace elements. They enrich the soil with humus, stimulate the activity of living beings in the soil which they serve as food (Manlay et al, 2007), stimulates the growth and development of plants (Atyieh et al, 2000a; Atiyeh et al, 2000b) and preserves the environment for reduce mineral fertilizers (Maynard, 2000).

This work aims to study the effects of four organic matter products, two Tunisians, one German and one French, used as soil conditioner on growth, crop parameters development and yield of pepper under greenhouses.

\section{Materials and methods}

\subsection{Methodology}

The present work aims to study the effects of organic 
Table1: Major elements content in each Organic amendment $(\mathrm{g} / \mathrm{kg})$ and treatment $(\mathrm{Kg} / \mathrm{Ha})$ used.

\begin{tabular}{|c|c|c|c|c|c|c|}
\hline Trématent & $\mathrm{N}(\mathrm{g} / \mathrm{Kg})$ & $\mathrm{P}(\mathrm{g} / \mathrm{kg})$ & $\mathrm{K}(\mathrm{g} / \mathrm{kg})$ & $\mathrm{N}(\mathrm{kg} / \mathrm{Ha})$ & $\mathrm{P}(\mathrm{kg} / \mathrm{Ha})$ & $\mathrm{K}(\mathrm{kg} / \mathrm{Ha})$ \\
\hline Control & 0 & 0 & 0 & 0 & 0 & 0 \\
\hline DM & $2,76^{*}$ & $2,64^{*}$ & $4,91^{*}$ & 151,8 & 145,2 & 270,6 \\
\hline CG & 10 & 20 & 30 & 10 & 20 & 30 \\
\hline CGDM & & & & 80,9 & 82,6 & 150,3 \\
\hline CF & 30 & 20 & 30 & 60 & 40 & 60 \\
\hline CT & 17,8 & 2,8 & 9,7 & 178 & 28 & 97 \\
\hline
\end{tabular}

* Obtained from the average of the results of analyzes of three samples

Table 2: Effect of organic amendments on pepper crop parameters var. Chargui starter at 150DAT

\begin{tabular}{|c|c|c|c|c|c|c|c|c|c|c|}
\hline Paramètre & \multicolumn{2}{|c|}{$\mathrm{H}(\mathrm{cm})$} & \multicolumn{2}{c|}{ DS $(\mathrm{cm})$} & \multicolumn{2}{c|}{ NB } & \multicolumn{2}{c|}{ LA $(\mathrm{cm} 2)$} & \multicolumn{2}{c|}{ DW $(\mathrm{g})$} \\
\hline $\mathrm{Vi} / \mathrm{Ti}$ & Starter & chargui & Starter & chargui & Starter & chargui & Starter & chargui & Starter & chargui \\
\hline $\mathrm{T} 0$ & $67,17 \mathrm{bc}$ & $75,33 \mathrm{a}$ & $1,33 \mathrm{a}$ & $1,45 \mathrm{a}$ & $5,33 \mathrm{a}$ & $4,33 \mathrm{a}$ & $1273,00 \mathrm{a}$ & $1300,44 \mathrm{a}$ & $19,00 \mathrm{a}$ & $19,50 \mathrm{a}$ \\
\hline $\mathrm{DM}$ & $73,67 \mathrm{a}$ & $67,50 \mathrm{a}$ & $1,45 \mathrm{a}$ & $1,37 \mathrm{a}$ & $4,83 \mathrm{a}$ & $5,00 \mathrm{a}$ & $1248,18 \mathrm{a}$ & $1174,49 \mathrm{a}$ & $20,00 \mathrm{a}$ & $16,00 \mathrm{a}$ \\
\hline $\mathrm{CG}$ & $65,17 \mathrm{bc}$ & $77,33 \mathrm{a}$ & $1,28 \mathrm{a}$ & $1,37 \mathrm{a}$ & $5,00 \mathrm{a}$ & $4,83 \mathrm{a}$ & $1239,13 \mathrm{a}$ & $1226,85 \mathrm{a}$ & $19,50 \mathrm{a}$ & $17,50 \mathrm{a}$ \\
\hline $\mathrm{CGDM}$ & $74,83 \mathrm{a}$ & $73,33 \mathrm{a}$ & $1,47 \mathrm{a}$ & $1,43 \mathrm{a}$ & $6,17 \mathrm{a}$ & $4,67 \mathrm{a}$ & $1237,18 \mathrm{a}$ & $1223,60 \mathrm{a}$ & $21,00 \mathrm{a}$ & $17,50 \mathrm{a}$ \\
\hline $\mathrm{CF}$ & $60,67 \mathrm{c}$ & $71,67 \mathrm{a}$ & $1,42 \mathrm{a}$ & $1,38 \mathrm{a}$ & $5,17 \mathrm{a}$ & $4,67 \mathrm{a}$ & $1161,59 \mathrm{a}$ & $1174,63 \mathrm{a}$ & $17,50 \mathrm{a}$ & $16,50 \mathrm{a}$ \\
\hline $\mathrm{CT}$ & $76,83 \mathrm{a}$ & $67,00 \mathrm{a}$ & $1,47 \mathrm{a}$ & $1,27 \mathrm{a}$ & $4,83 \mathrm{a}$ & $4,50 \mathrm{a}$ & $1164,59 \mathrm{a}$ & $1265,50 \mathrm{a}$ & $18,00 \mathrm{a}$ & $18,00 \mathrm{a}$ \\
\hline
\end{tabular}

NB: The values assigned by the same index are not significantly different at $5 \%$ risk of error.

amendments on greenhouse pepper. It proposes to compare six treatments:

- A control treatment (T0) for which no organic matter supply is made.

- T1 treatment for which 55 t/ha of well-rotted cattle manure (DM)

- T2 treatment for which commercial German compost (CG) containing $85 \% \mathrm{OM}$ is made at $1 \mathrm{t} / \mathrm{ha}$.

- T3 treatment for which CG at $0.5 \mathrm{t} / \mathrm{ha}(50 \%$ of the recommended dose ) in addition to DM at $27.5 \mathrm{t} / \mathrm{ha}, 50 \%$ of the usual dose greenhouse, ( CGDM) is made.

- T4 treatment for which French compost $(\mathrm{CF})$ containing $60 \% \mathrm{OM}$ is brought to a rate of $2 \mathrm{t} / \mathrm{ha}$.

- T5 treatment for which Tunisian compost (CT) containing $70 \% \mathrm{OM}$ is made at $10 \mathrm{t} / \mathrm{ha}$.

The manure dose was chosen considering the soil characteristics (sandy), the initial OM content (1.7\%) and the practices of the majority of farmers in the region. For the rest of organic products used in this experiment, the doses were suggested by the technical direction of the respective companies responsible for the marketing of each product. Table 1 summarizes the major elements of intake in $\mathrm{g} / \mathrm{kg}$ of each product and $\mathrm{kg} / \mathrm{ha}$ of each proposed treatment.

Mineral fertilization was similar for all treatments and was calculated on the basis of crop exports (Odet et al, 1989) for fruit yield expected of $80 \mathrm{t} / \mathrm{ha}$.

\subsection{Experimental device}

The experiment was conducted at Soukra (Tunisia), located at $36^{\circ} 52^{\prime} \mathrm{N} 10^{\circ} 15^{\prime} \mathrm{E}$, in three greenhouses oriented North-South. Planting was done in twin rows of Starter variety (V1) and Chargui variety (V2) of pepper.
The experimental design adopted is a split-plot in 6 repetitions with 2 variation factors: organic amendments and pepper varieties.

\subsection{Measured parameters}

- Crop Growth Parameters at 150 days after transplanting (DAT): Plant Height $(\mathrm{H}) \mathrm{cm}$, stem diameter (DS) in $\mathrm{cm}$ measured using calipers at the first bifurcation, the number of bifurcations (NB), the leaf area (LA) in $\mathrm{cm}^{2}$ using a planimeter, and dry biomass of aerial parts (DW) measured after oven drying at $70^{\circ} \mathrm{C}$ for 48 hours.

- Flowering and Fruiting Parameters at 150 (DAT): Number of flowers present (Nf) Number of fruit set (Nfs)

- Yield Parameters at 150 (DAT): Number of harvested fruit (NFY), fruit weight harvested (WFY) and precocity (P) calculated by the ratio of WFY 150 DAT and cumulative WFY 150, 157, 185 and 210 DAT.

\section{Statistical Analysis}

Analysis of variance (ANOVA) of data for measured parameters was carried out by SPSS statistical program version 19, and means comparison was performed by Duncan test at $5 \%$ and $10 \%$ level.

\section{Results and discussion}

Amendments by different types of organic conditioner used did not cause effects on stem diameter, number of bifurcation, leaf area and plant dry matter of pepper at 150 DAT for both varieties tested (table 2). 
Table 3: Effect of organic amendments on the flowering and fruiting parameters of var. chargui and starter pepper 150 DAT

\begin{tabular}{|c|c|c|c|c|}
\hline Parameter & \multicolumn{2}{|c|}{ Nf } & \multicolumn{2}{c|}{ Nfs } \\
\hline $\mathrm{Vi} / \mathrm{Ti}$ & Starter & chargui & Starter & Chargui \\
\hline $\mathrm{T} 0$ & $14,83 \mathrm{bc}$ & $13,33 \mathrm{a}$ & $13,17 \mathrm{c}$ & $14,83 \mathrm{bc}$ \\
\hline $\mathrm{DM}$ & $17,33 \mathrm{ab}$ & $12,83 \mathrm{a}$ & $19,00 \mathrm{ab}$ & $18,17 \mathrm{ab}$ \\
\hline $\mathrm{CG}$ & $13,50 \mathrm{bc}$ & $11,67 \mathrm{a}$ & $14,83 \mathrm{c}$ & $19,00 \mathrm{ab}$ \\
\hline $\mathrm{CGDM}$ & $16,67 \mathrm{~b}$ & $13,33 \mathrm{a}$ & $17,83 \mathrm{~b}$ & $21,17 \mathrm{a}$ \\
\hline $\mathrm{CF}$ & $13,50 \mathrm{bc}$ & $12,67 \mathrm{a}$ & $12,00 \mathrm{c}$ & $16,67 \mathrm{bc}$ \\
\hline $\mathrm{CT}$ & $13,83 \mathrm{bc}$ & $12,00 \mathrm{a}$ & $22,33 \mathrm{a}$ & $13,83 \mathrm{c}$ \\
\hline
\end{tabular}

NB: The values assigned by the same index are not significantly different at $5 \%$ risk of error.

Table 4: Effects of organic amendments on yield parameters of var. chargui and starter pepper 150 DAT.

\begin{tabular}{|c|c|c|c|c|c|c|c|c|}
\hline Paramètre & \multicolumn{2}{|c|}{ NFY } & \multicolumn{2}{c|}{ WFY $(\mathrm{g})$} & \multicolumn{2}{c|}{ mWFY $(\mathrm{g})$} & \multicolumn{2}{c|}{$\mathrm{P}(\%)$} \\
\hline Vi/Ti & Starter & chargui & Starter & chargui & Starter & chargui & Starter & chargui \\
\hline T0 & $10,50 \mathrm{bc}$ & $21,67 \mathrm{~b}$ & $287,50 \mathrm{bc}$ & $626,67 \mathrm{c}$ & $27,38 \mathrm{a}$ & $28,92 \mathrm{c}$ & $7,80 \mathrm{bc}$ & $12,28 \mathrm{bc}$ \\
\hline DM & $14,83 \mathrm{ab}$ & $27,00 \mathrm{a}$ & $390,83 \mathrm{a}$ & $860,00 \mathrm{a}$ & $26,35 \mathrm{a}$ & $31,85 \mathrm{ab}$ & $10,57 \mathrm{ab}$ & $23,98 \mathrm{ab}$ \\
\hline CG & $12,50 \mathrm{bc}$ & $28,00 \mathrm{a}$ & $310,00 \mathrm{bc}$ & $814,17 \mathrm{ab}$ & $24,80 \mathrm{a}$ & $29,08 \mathrm{c}$ & $7,29 \mathrm{bc}$ & $21,11 \mathrm{ab}$ \\
\hline CGDM & $13,67 \mathrm{ab}$ & $29,17 \mathrm{a}$ & $380,00 \mathrm{a}$ & $947,50 \mathrm{a}$ & $27,80 \mathrm{a}$ & $32,49 \mathrm{ab}$ & $9,97 \mathrm{ab}$ & $21,32 \mathrm{ab}$ \\
\hline CF & $9,50 \mathrm{c}$ & $18,67 \mathrm{~b}$ & $263,33 \mathrm{bc}$ & $527,50 \mathrm{c}$ & $27,72 \mathrm{a}$ & $28,26 \mathrm{c}$ & $6,14 \mathrm{bc}$ & $14,50 \mathrm{c}$ \\
\hline CT & $14,50 \mathrm{ab}$ & $22,83 \mathrm{~b}$ & $402,50 \mathrm{a}$ & $762,50 \mathrm{~b}$ & $27,76 \mathrm{a}$ & $33,39 \mathrm{a}$ & $16,60 \mathrm{a}$ & $19,17 \mathrm{~b}$ \\
\hline
\end{tabular}

NB: The values assigned by the same index are not significantly different at $5 \%$ risk of error.

CT, DM and CGDM increased plant height of pepper starter variety $76.83 ; 74.83$ and 73.67 respectively (Figure 1). This effect was not observed on Chargui variety, which tends to be higher than starter.

The DM showed a positive effect on flowering and fruit set of starter variety when applied alone or mixed with GC, but the best fruit set was recorded with the CT (Figure 2.3). For chargui variety CGDM, CG and DM had a significant impact on fruit set (Figure 3), although no significant effect on flowering was observed (Figure 2). Table 3 summarizes the effect of organic amendments applied to the parameters of flowering and fruiting of the two pepper varieties tested.

Response of starter and chargui varieties of pepper for the application of organic amendments on yield parameters was significant $(10 \%)$ and highly significant $(5 \%)$ respectively (Table 4$)$.

Amendments application of CGDM , DM and CG led to the best WFY and NFY 947.5; 860 and $814.17 \mathrm{~g}$ and $29.17 ; 27$ and 28 respectively, at 150 DAT for chargui variety (Figure 4 and 5 ), with a maximum improvement in the NFY of $38 \%$ and WFY of $40 \%$ for the CT compared to control.

CT, DM and CGDM generated the best yield performance (WFY) for starter variety at 150 DAT: 402.5 ; 390.83 and $380 \mathrm{~g}$ respectively which also results in NFY (figure 4 and 5 ), with a maximum improvement in the NFY of $34 \%$ and WFY of $51 \%$ for the CGDM treatment compared to control.

Organic amendments CT, CGDM and CG improved fruit size calculated by the mean of the weight by the number of fruit yielded (mWFY) of chargui variety at 150 DAT (figure 6).

CT , DM and CGDM improved The precocity of pepper starter variety respectively to values of $12.6 \%$,
$10.57 \%$ and $9.97 \%$, with a maximum relative improvement of $61 \%$ for CT compared to control (figure 7).

DM, CGDM and CG helped to improve the precocity (P) of pepper Chargui at respective rates of $29.98 \%$, 21.32 and $21.11 \%$, with a maximum relative improvement of $64 \%$ for DM compared to control (figure 8).

The positive effects of organic amendments on pepper crop has been proven on the functional activity of the photosynthetic apparatus (Berova and Karanatsidis , 2009; Karakurt et al, 2009), the growth of stems, roots and leaf size (Berova and Karanatsidis , 2009).

Concentrations of humic acid in organic amendments could be the source of improving the precocity and fruit size and total yield of pepper (Karakurt et al, 2009) and quality and yield of cucumber (OzdamarUnlu et al., 2011), the growth of plants heights, leaf area and yield (ElHefny, 2010) on cowpea crop; and plant growth, root

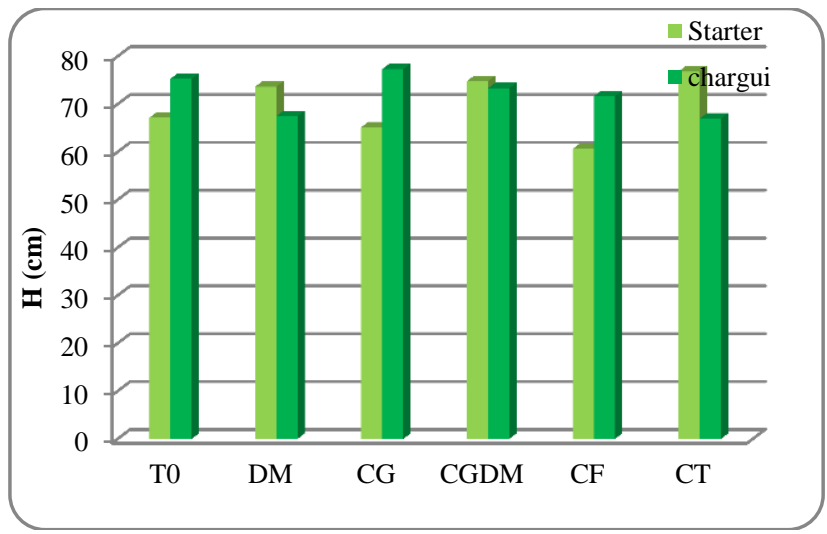

Figure 1: Effects of organic amendments on Height $(\mathrm{H})$ $\mathrm{cm}$ at 150 DAT for var. starter and chargui pepper . 


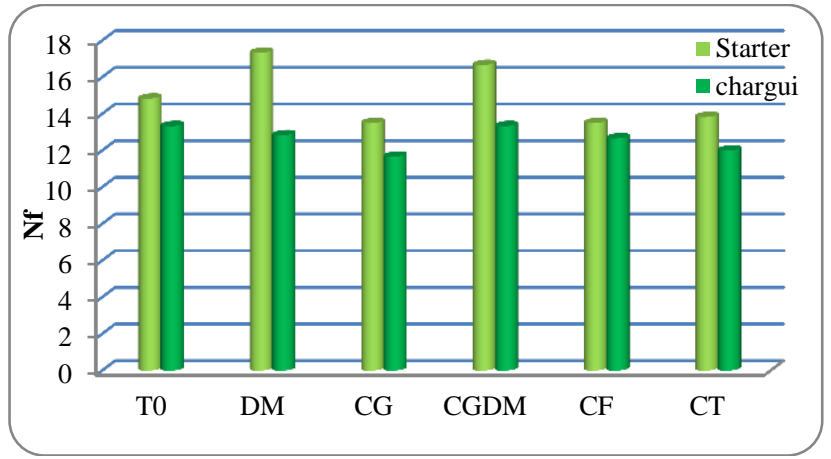

Figure 2: Effects of organic amendments on Number of flowers (Nf) at 150 DAT for var. starter and chargui pepper

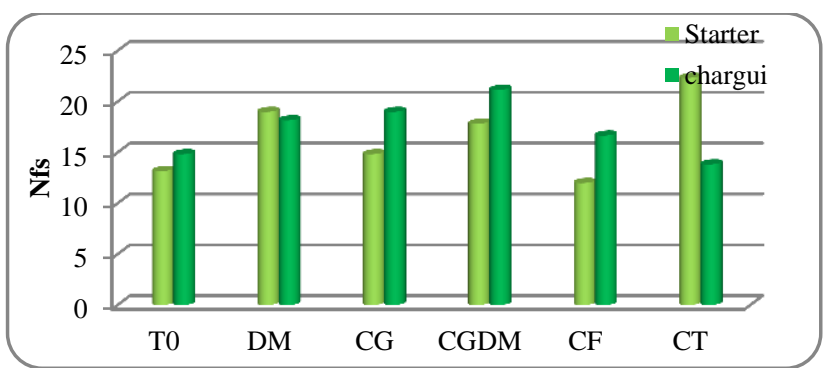

Figure 3: Effects of organic amendments on Number of fruit set (Nfs) at 150 DAT for var. starter and chargui pepper

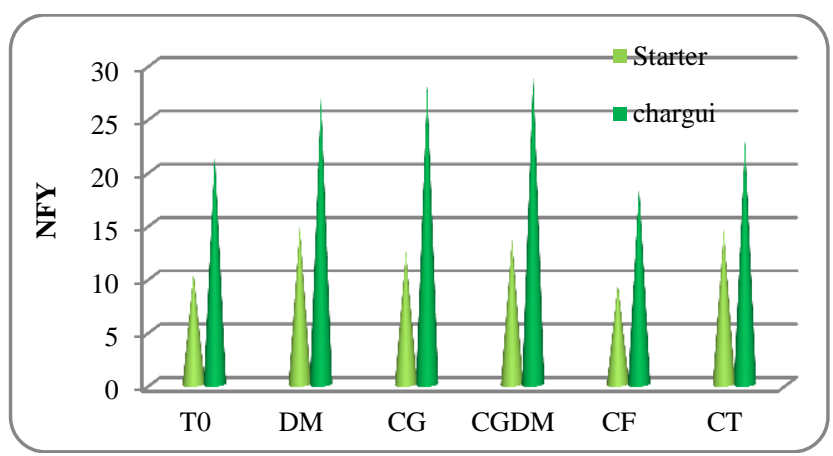

Figure 4: Effects of organic amendments on Number of fruit yielded (NFY) at 150 DAT for var. starter and chargui pepper

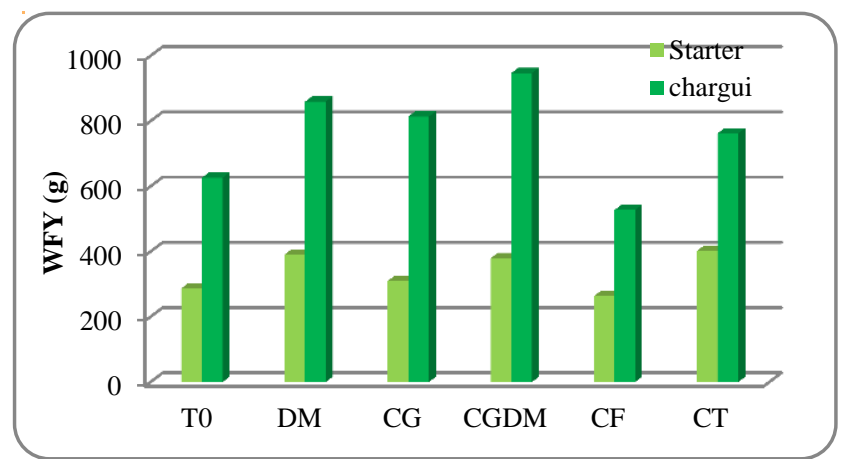

Figure 5: Effects of organic amendments on weight of fruit yielded (WFY) at 150 DAT for var. starter and chargui pepper

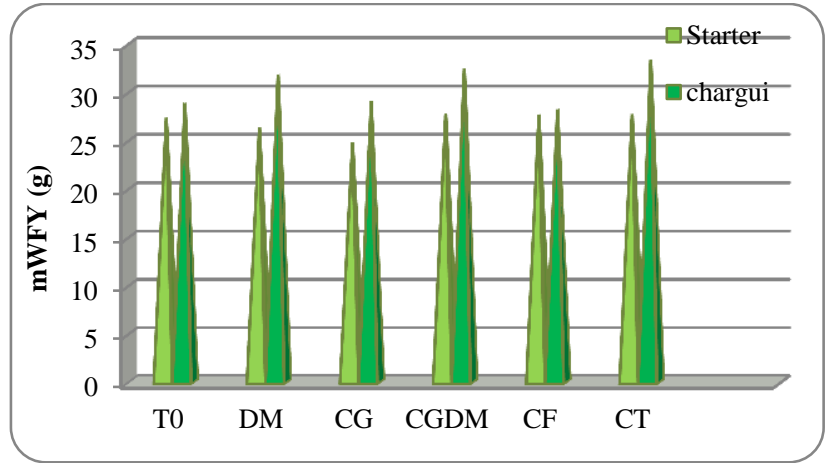

Figure 6: Effects of organic amendments on fruit size (mWFY) at 150 DAT for var. starter and chargui pepper

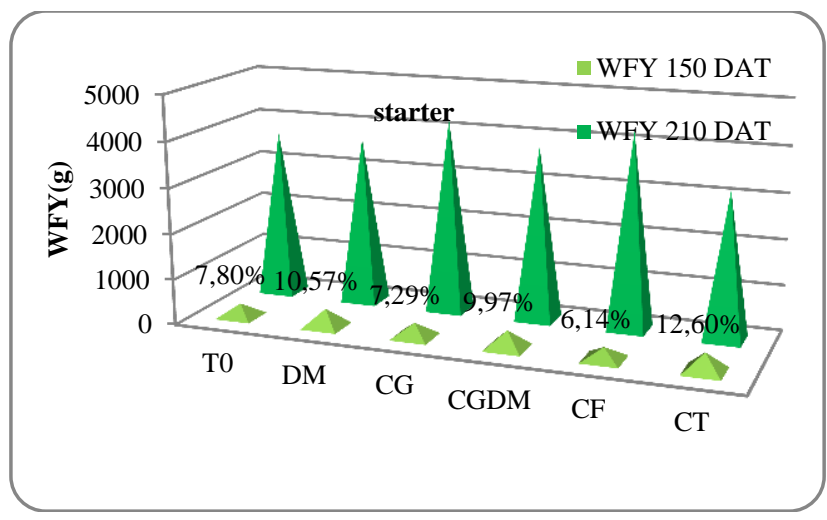

Figure 7: Effects of organic amendments on precocity of fruit for starter var. of pepper

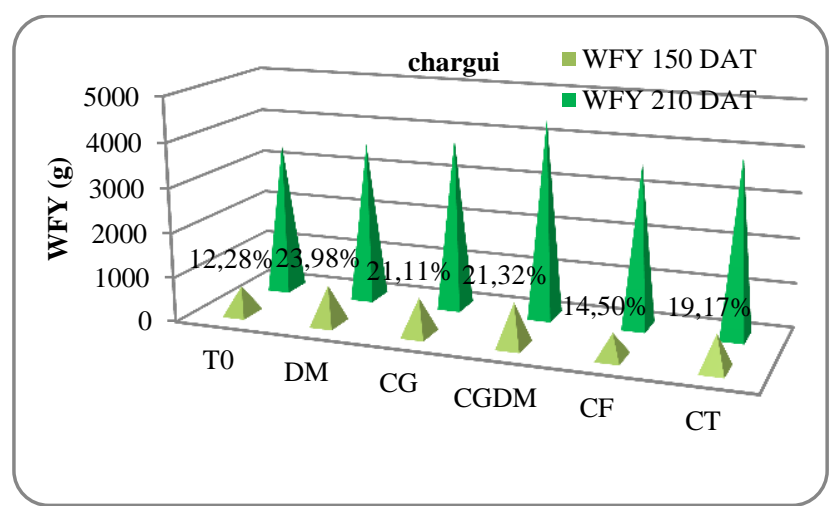

Figure 8: Effects of organic amendments on precocity of fruit for chargui var. of pepper

growth and flower and fruit numbers of pepper (Norman et al, 2009).

The improvement in the number of harvested fruit is the source of improvement of the registered yield (Maynard, 1996) .

The results found shows a difference in the effects of organic amendments on height growth, flowering, fruit set, fruit size and earliness of chargui and starter varieties that could be attributed to varietal behavior of pepper (Tarchoun and Mougou, 2009) .

CF showed no significant effect on the two varieties of pepper crop, the dose of $2 \mathrm{~T} / \mathrm{Ha}$ proposed by the technical manager of the company selling the product can be insufficient in mineral intake (Table 1) and humic 
contribution. Test of higher doses are needed to perform the suitable application for significant effects.

\section{Conclusion}

Organic amendments, manure or commercial composts alone or combined, allow to improve fruit set, yield in number and weight and earliness of pepper crop. The behavior of the pepper crop under organic amendments for plant height, flowering and size remains dependent on the varietal response.

\section{Acknowledgements}

The development of this work has been achieved with the valuable contribution of Henda and Sameh technicians in vegetable crops laboratory of INAT and Dr. Anis Elaoud from CERTE (research center in Water Technology Borj Cedria) Tunisia.

\section{References}

Aboudrare A., 2009, Agronomie Durable. Principes et Pratiques. Rapport de Formation Continue. FAO 2009, 49 pages .

Atiyeh R., Edwards C., Subler S., Metzger J., 2000a, Pig manure vermicompost as a component of a horticultural bedding plant medium: effects on physicochemical properties and plant growth, Bioresource technology 2000 78, 1: 11-20.

Atiyeh R., Arancon N., Edwards A., Metzeger J., 2000b, Influence of earthworm-produced pig manure on the growth and yield of greenhouse tomatoes, Bioresource Technology $200075,3: 175-180$.

Beji S.,2010, Effet du choix variétal et de la fertilisation organique sur le rendement et la qualité technologique du blé dur (TriticumdurumDesf.) cultivé en agriculture biologique. Thèse de Doctorat en sciences agronomique de l'INATTunisie. 144 pages.

Berova M., Karanatsidis G., 2009, Physiological response and yield of pepper (capsicum annum L.) plants to organic fertilization. J. Cent. Eur. Agric. (2008) 9:4, 715-722.

Bressoud F., Arrufat A., 2009, Amendements organiques et maraîchage biologique sous abri - Observations après 6 années d'apport. Innovations Agronomiques 4, 15-21.

Calbrix R., 2005, Impact des produits organiques et des conduites culturales sur la biomasse microbienne et la diversité des bactéries telluriques. Thèse de doctorat de l'université de Rouen et de l'Esitpa, 167 pages.

Delate K., 2002, Using an agroecological approach to farming systems research, HortTechnology (2002) 12, 3:345-354.
El-Hefny, E.M., 2010, Effect of saline irrigation water and humic acid application on growth and productivity of two cultivars of cowpea (Vignaunguiculata L. Walp). Aust. J. Bas. Appl. Sci., 4: 6154-6168

Fuchs J., 2003, Le compost de qualité au service de la santé des plantes. Alternative Agriculture 61, 7-9.

Ibrahima A. ,Abib Fanta C., Ndjouenkeu R., 2010, Impact de la gestion de la matière organique sur le statut minéral des sols et des récoltes dans les savanes soudano-guinéennes de Ngaoundéré, Cameroun . Actes du colloque «Savanes africaines en développement : innover pour durer».

Karakurt Y.,UnluHusnu, UnluHalim, Padem H., 2009, The influence of foliar and soil fertilization of humic acid on yield and quality of pepper. Actaagriculturaescandinavica - Section B soil \& plant science, 2009; 59: 233-237.

Laurence W., 1998, Dynamique et biomasse des fragments de la forêt amazonienne. Actualités des Forêts tropicales, Bulletin de l'OIBT, $6: 12-13$.

Manlay R.J., Feller C., Swift M.J., 2007, Historical evolution of soil organic matter concepts and their relationships with the fertility and sustainability of cropping systems.Agriculture, Ecosystems\&Environment, Volume 119, Issues 3-4, Mars 2007 , Pages 217-233.

Maynard, A.A. 1996, Cumulative effect of annual additions of undecomposed leaves and compost on the yield offield-grown peppers. Compost Science and Utilization 4(2):81-88

Maynard A.A., 2000: Compost: The process and research. The connecticut Agricultural Experment Station New Haven. Bulletin 966, july 2000.13p.

Mustin M., 1987, Le compost, gestion de la matière organique, François Dubusc (Edn), Paris,954p.

Norman Q. Arancon, Clive. A. Edwards, Stephen Lee, Robert Byrne, 2009, Effects of humic acids from vermicomposts on plant growth , European Journal of Soil Biology, Volume 42, Supplement 1, November 2006, Pages S65-S69

OzdamarUnlu H., Unlu H., Karakurt Y., and Padem H., 2011, Changes in fruit yield and quality in response to foliar and soil humic acid application in cucumber. Scientific Research and Essays Vol. 6(13), pp. 2800-2803, 4 July, 2011. Available online at the link http://www.academicjournals.org/SRE

Odet J., Musard M., Wacquant C., Puel, T., Alegot, M., 1989, Mémento fertilisation des cultures légumières. Edition Ctifl, 398 pages.

Tarchoun N., and Mougou A., 2009, Combining ability and heterosis for earliness flowring and fructification on pepper (capsicum annum L.) grown under low night temperature. International Journal of plant Breeding, 2009, Global Science Books.

Thuriès L., Arrufat A., Dubois M., Feller C., Hermann P., LarréLarrouy M.C., Martin C., Pansu M., Rémy J.C., Viel M., 2000 Influence d'une fertilisation organique et de la solarisation sur la productivité maraîchère et les propriétés d'un sol sableux sous abri. Etude et Gestion des Sols 7, 215-229. 